\title{
The Impact of Inflation Uncertainty on the Labor Market
}

\section{A. Steven Holland}

A the last 20 years the impact of inflation has become a topic of widespread interest. Evidence suggests that higher inflation imposes real costs on society by leading to increased uncertainty about future inflation and, as a result, a misallocation of resources. "This article examines the impact of inflation uncertainty on the allocation of labor resources and shows that the economy produces less output with a given quantity of productive resources when inflation uncertainty is higher. ${ }^{2}$

\section{LABOR MARKET RESPONSE TO UNANTICIPATED INFLATION}

The labor market's reaction to unanticipated inflation depends upon the flexibility of nominal wages. As a general rule, both the quantity of labor services that

A. Steven Holland is an economist at the Federal Reserve Bank of St. Louis. Jude L. Naes, Jr. provided research assistance. The author wishes to thank Daniel Hamermesh for comments on an earlier draft.

"For a discussion of the relationship between inflation and inflation uncertainty, see Holland (1984). The best-known discussion of the potential adverse impacts of intlation uncertainty is by Friedman (1977).

Inflation uncertainty also may affect markets other than the labor markel. For a discussion of its impact on product markets, see Cariton (1982); on financial markets, see Kantor (1983). For a broad overview, see Fischer (1982). An alternative approach to that used in this paper would be to consider information a productive resource and analyze the effects of a reduction in the sevel of this resource. workers supply and the quantity that business firms demand depend upon the real wage rate - the nominal wage rate adjusted for the level of prices. The in teraction of the supply and demand for labor determines the equilibrium value of the real wage; the nominal wage adjusts upward or downward as inflation or deflation occurs. Figure 1 shows the labor market in equilibrium at a real wage $w_{1}^{*}$ with employment $Q_{1}^{*}$, when the supply of labor is $S_{t}$ and the demand for labor is $D_{1}$. If the nominal wage were completely flexible that is, if it adjusted instantly to keep the real wage constant in the face of changing rates of inflation then unanticipated inflation would have no effect on the labor market. Nominal wages simply would rise or fall, maintaining equilibrium at $w_{1}^{*}$ and $\mathrm{Q}_{1}^{*}$.

\section{Nominal Wage Rigidity}

Wages are not perfectly tlexible, however, because of contractual arrangements that prevent their immediate adjustment to changes in prices. For example, in a contract for union workers, the nominal wage is fixed for a specified period of time. Although less than 25 percent of the U.S. labor force is mionized, the impact of union wage contracts extends far beyond this group. If there is a threat of unionization, for example, the wage increases won for union laborers will affect the wages that nonunionized firms offer their employees. 3

"Famermesh and Rees (1984) discuss the arguments for and against
the notion that the wages of nonunion workers emulate hose of union workers. 


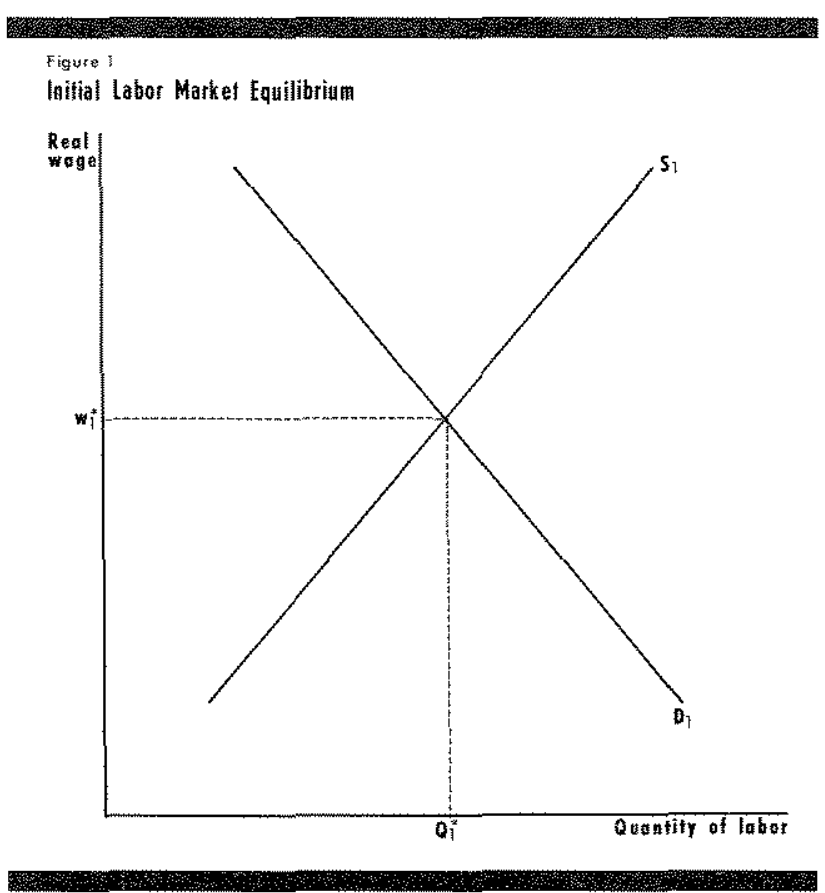

In addition, there are many implicit agreements between employers and employees that keep nominal wages fixed for a specified period. ${ }^{+}$Oftentimes, both employers and employees recognize that it would be too costly for nominal wages to adjust to every temporary deviation of actual events from the expected.

The contracted nominal wage is determined in essentially the same manner as in the flexible-wage case. The only difference is that $w_{1}^{*}$ in figure 1 is now the equilibrium expected real wage - the nominal wage adjusted for the expected level of prices - rather than the equilibrium actual real wage."

If nominal wages are rigid in the short run, the actual differs from the expected real wage when there is unanticipated inflation. If the inflationary shock is permanent, then the nominal wage contract must ultmately be renegotiated. Recontracting, however, will not occur immediately unless the shock is of sufficient magnitude in absolute terms) for the gains from immediate recontracting to exceed the costs. Otherwise, an unanticipated short-run redistribution of wealth occurs.

Furthermore, assuming a downward sloping de-

\footnotetext{
${ }^{4}$ See Azariadis (1975) and Baily (1974).

5 assume that both the suppliers and demanders of labor expect the same rate of inflation to occur.
}

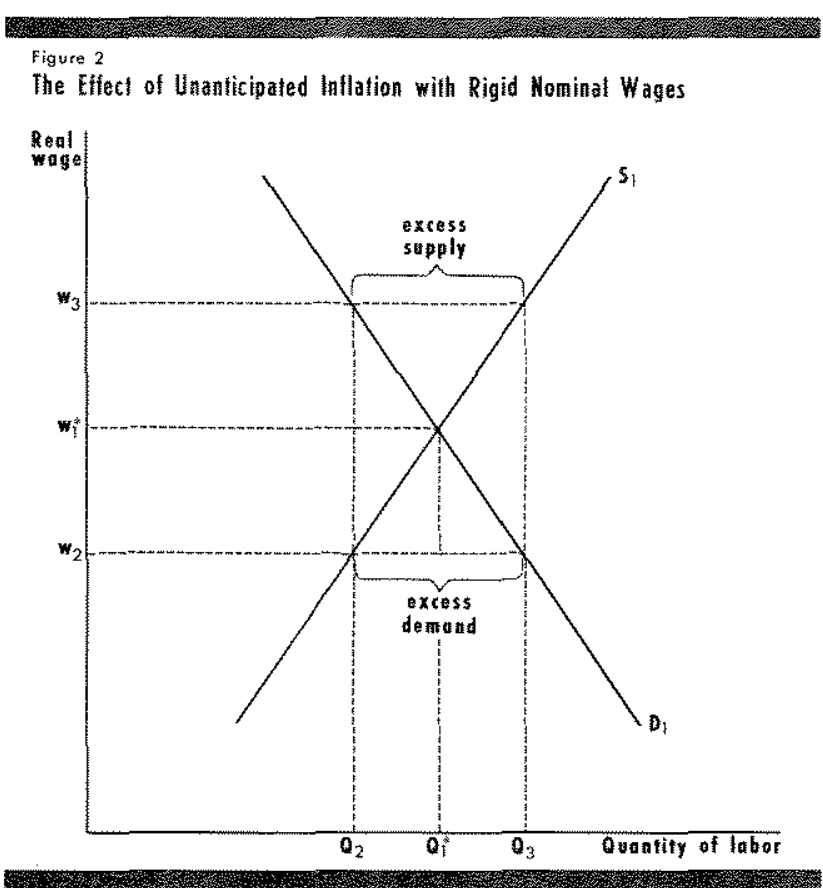

mand for labor curve and an upward-sloping supply of labor curve, a deviation in either direction of actual from anticipated inflation results in reduced employment. This is illustrated in figure 2. With inflation higher than previously expected, the actual real wage is $w_{2}$ which is less than the equilibrium expected real wage $w_{7}^{*}$. This results in a reduction of employment from $Q_{1}^{*}$ to $Q_{2}$ and an excess demand for labor $\left(O_{3}-Q_{2}\right)$. With lower-than-expected inflation, the actual real wage is $w_{3}$ which is greater than $w_{1}^{*}$. This also results in a reduction of employment lagain drawn at $\mathrm{Q}_{2}$ for ease of exposition but with excess supply of labor $\left(Q_{3}-Q_{2}\right)$. Notice that both the supply and demand curves are more steeply sloped in figure 2 than in figure 1. This is because the elasticity of both supply and demand with respect to the actual real wage should be less in absolute value for this short-men case than it in the long run, because both workers and firms would like to avoid immediate recontracting if possible.

In reality, nominal wages have varying degrees of flexibility because of differences in the characteristics

\footnotetext{
${ }^{6}$ Many theorists, including Gray (1976), Fischer (1977a) and Katz and Rosenberg (1983) use models in which nominal wages are determined by contract and business firms adjust employment in accordance with the realized value of the real wage. Therefore, in these models, employment is completely demand-determined, and higherthan-expected inflation results in a higher level of employment because of the lower real wage. For a critique of this type of model, see Barro (1977).
} 


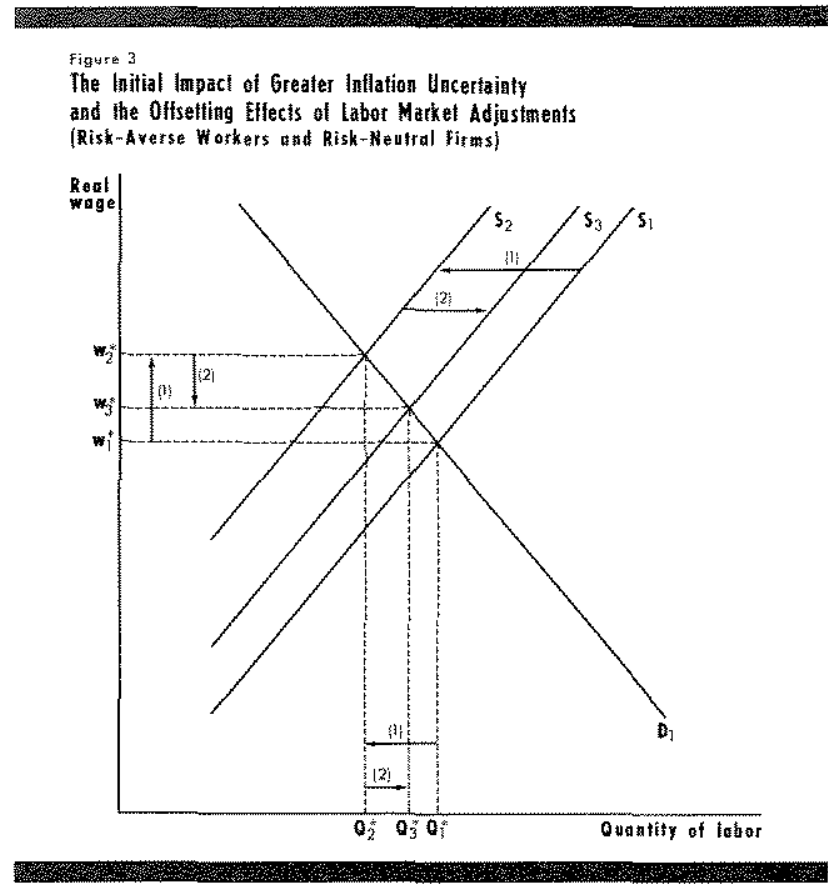

of wage contracts. Therefore, some combination of the flexible- and rigid-wage models describes actual labor market behavior.

\section{INTTAL EFFECTS OF GREATTR INFLATION UNCERTAINTY}

Greater uncertainty about inflation increases the risk of entering into wage contracts. There is a much greater potential for error in forecasting inflation, which increases the potential deviation of actual from expected real wages. Under reasonable assumptions, this increase in risk has the effect of reducing employment and increasing the costs of negotiating a given labor contract.

This analysis assumes that workers are risk-averse, business firms are risk-neutral and nominal wages are fairly rigid. As the level of inflation uncertainty increases, risk-averse workers reduce the supply of labor offered to the market. They redirect their activities

\footnotetext{
${ }^{7}$ The assumption of risk-averse workers and risk-neutral firms is used frequently in the literature on labor contracting; see, for example, Azariadis. One reason, as explained by Gordon (1974), is that it is more difficult to reduce the risk associated with owning human capifat than physical capital. For example, people tend to be specialized in their labor skills, whereas their other capital holdings tend to be diversified.

${ }^{8}$ Amihud (1981) presents a model that leads to this result.
}

toward those that are affected less by unanticipated inflation. Aside from opting for greates income from more effectively hedged capital holdings, they devote more time to leisure or to labor provided outside the market - for example, labor exchanged directly for goods and services or labor for one's own benefit such as home improvements. This is illus trated in figure 3 by a movement of the supply curve from $S_{\text {f }}$ to $S_{2}$. Because the demand for labor by risk-neutral business firms is unaffected by greater inflation uncertainty, the demand curve $\left(D_{1}\right)$ remains stationary. Labor contracts will be revised so that the equilibrium expected real wage rate rises from $w_{i}^{*}$ to $w_{2}^{*}$ and the equilibrium level of employment falls from $\mathrm{O}_{1}^{*}$ to $\mathrm{O}_{2}^{*}$. Reduction of employment will also reduce the level of real output and possibly increase the rate of unemployment. ${ }^{ \pm 0}$

Greater inflation uncertainty increases the complexity of wage negotiations, because of the potential for increased loss to both the employer and emplovee from incorrectly choosing the nominal wageadjustment mechanism or contract duration. If wages are not indexed, it becomes more difficult to determine the appropriate nominal wage changes to incorporate in the contract. If wages are indexed, there remain the problems of choosing the "best" index to use for nominal wage adjustments and the extent to which wages will be adjusted for changes in the index. Other potential considerations are whether to set caps on the size of cost-of-living adjustments and the conditions under which contract negotiations will be reopened before expiration of the contract. Thus, the costs of negotiating a labof contract increase with inflation uncertainty."

\footnotetext{
9If both firms and workers ate tisk averse, then employment falls even more, but the effect on the equilibritum real wage is indeterminate.

${ }^{10}$ The measured rate of unemployment may increase despite the occurrence of equitibrium in the labor market, because of people continuing to search for a job even though they're unwiling to accept one at the prevaiting wage rate. Recent studies by Mullineaux (1980), Levi and Makin (1980), Ratti (1983) and Aminud indicate that greater inflation uncertainty reduces employment and output growth and increases unemployment.

${ }^{11}$ One indicator of the higher costs of negotiating labor contracts would be an increase in strike activity, since the increased complexity of negotiations makes it more difficult to reach a settement. Labor economists have known for many years that past inftation has a significant positive impact on the incidence of labor strikes. See, tor example. Ashentelter and Johnson (1969). The standard explanation is that this reflects catch-up demands on the part of labo: for inftation they did not anticipate and, therefore, were not compensated for at the tme of previous contract negotiations. Given the evidence that inflation uncertainty is positively related to past inflation (see Holland), this finding is consistent with the notion that greater inflation uncertainty leads to more strike activity.
} 
Inflation uncertainty also makes it more difficult to distinguish changes in the rate of inflation from changes in relative prices: an increase in inflation unctrtainty reduces the extent to which a producer alters his output in response to a change in the relative price of his product." The reason is that a producer will be less likely to regand an unexpectedly higher price for his product as an increase in its relative price. Instead, he will regard it as a reflection of his owm inability to accurately predict the rate of inflation. In this way, the alocative efficiency of the price svstem is reduced, since labor and other resources will not necessarily be directed toward their most productive uses ${ }^{13} \mathrm{All}$ things equal, if the marginal product of labor declines, the demand for labor and the equilibrium real wage falls. This would imply an even greater reduction in employment than that illustrated in figure 3 .

\section{ADAPTING TO INFLATION UNCERTAINTY}

There are two basic ways to reduce the risk of wage contracting in an environment of inflation uncertainty: (1) shorten the duration of contracts, thus lessening the potential loss from an incorrect prediction of infla ${ }^{*}$ tion, or $\{2\}$ index contracts, with wage adjustments linked to changes in the price level. Each of these adaptations will increase the responsiveness of nominal wages to an inflationary shock.

\footnotetext{
${ }^{12}$ For a producer to increase output in the short run, he must be able to increase employment. This requires either some flexibilty of nominal wages or demand-determined employment in the short run.

${ }^{13}$ See Lucas (1973) and Friedman. The confusion between relative and absolute price changes implies that the greater the inflation uncertainty, the less the effects on the firm's output, labor demand and wages of an actual change in the relative demand for its product. Therefore, greater inftation uncertainty reduces the impact of an increase in the variance of changes in relative product demands on the variance of changes in relative wages, assuming that nominal wages are flexible. To the extent that changes in relative wages assist in allocating labor in the most efficient manner, this indicates a potential loss of efficiency. This may explain Hamermesh's (1983) finding that greater inflation uncertainty reduces the variance of changes in relative wages in the United States.

Another way that intlation uncertainty may affect the productivity of labor arises because greater inflation uncertainty should be associated with greater variance over time of unanticipated inflation. If the level of employment varies with short-tem changes in the real wage due to unanticipated inflation, then the variance of employment is positively associated with inflation uncertainty. Katz and Rosenberg show that, if there are diminishing returns to the use of labor input, then the productivity of labor declines on average as the (mean-preserving) variance of employment gets higher. Therefore. greater infiation uncertainty reduces fabor productivity. (This result holds even if the mean level of employment declines as a result of the uncertainty.)
}

There is evidence that greater inflation uncertainty has served to reduce the duration of labor contracts. Using data from the unionized sector of the Canadian labor market for 1966-75, Christofides and Wilton 1983 find a significant negative relationship between inflation uncertainty and the length of contracts. Thus, greater inflation uncertainty diverts more resources to the contracting process from other ipreviously more valuable uses, not only because negotiations are more complex, but also because negotiations occur more frequently.

Greater inflation uncertainty also is associated with more widespread indexation of labor contracts. Chart 1 plots a measure of inflation uncertainty - the rootmean-squared errof (RMSE) of 12 -month inflation forecasts from the Livingston survey - and a measure of the prevalence of indexation - the number of workers covered by cost-of-living adjustment (COLAl clauses as a percentage of the total number of workers subject to major collective bargaining agreements. ${ }^{14}$ When viewed over the last 20 years, inflation uncertainty shows a rising trend, although with substantial variability. Over the last 10 years, however, the trend has

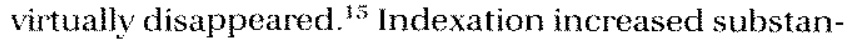
tially in the $1960 \mathrm{~s}$ and $1970 \mathrm{~s}$ as well, before levelling off. From 1967 77, COLA coverage rose from about 25 per" cent to its peak of over 60 percent and has remained fairly stable since then.

Simple cornelations suggest that inflation uncertainty has a lagged effect on the prevalence of indexation. The colvelation coefficients are not significant between COLA coverage and RMSE in the current or previous vear. The correlation of COLA coverage with RMSE two vears before $(0.44)$, however, is significant at the 10

\footnotetext{
${ }^{14}$ Joseph Livingston of The Philadelohia Inquirer conducts a survey each spring and tall requesting respondents to indicate their predictions about a number of economic indicators including the consumer price index (CPI). I use only the year-end to year-end forecasts in this article. The inftation forecasis are actually 14 -month forecasts since respondents are thought to know only the level of the October CPI when they turn in their predictions in December of the level of the CPl for the following December. With this in mind, Carlson (1977) has revised Livingston's data on inflation expectations, and this revised data (updated through 1983) is used here. The use of the mean-squared errof of the forecasts as a measure of inflation uncertainty is advocated by Cukierman and Wachtel (1982). The data on cost-of-living adjustments come from various issues of the Monthly Labor Review (see U.S. Department of Labor). Major col. lective bargaining agreements are those that apply to 1,000 or mofe workers. Although this is not a comprehensive indicator of the incidence of COLA coverage, it does cover the majority of all workers covered by COLA provisions. See Sheifer (1979).

${ }^{15}$ Regressions of RMSE on a time trend for the periods $1964-83$ and $1974-83$ confirm this perception.
} 


\section{Chart 1}

\section{Inflation Uncertainty and the Percentage of Workers Covered by Cost-of-Living Adjustment Clauses}

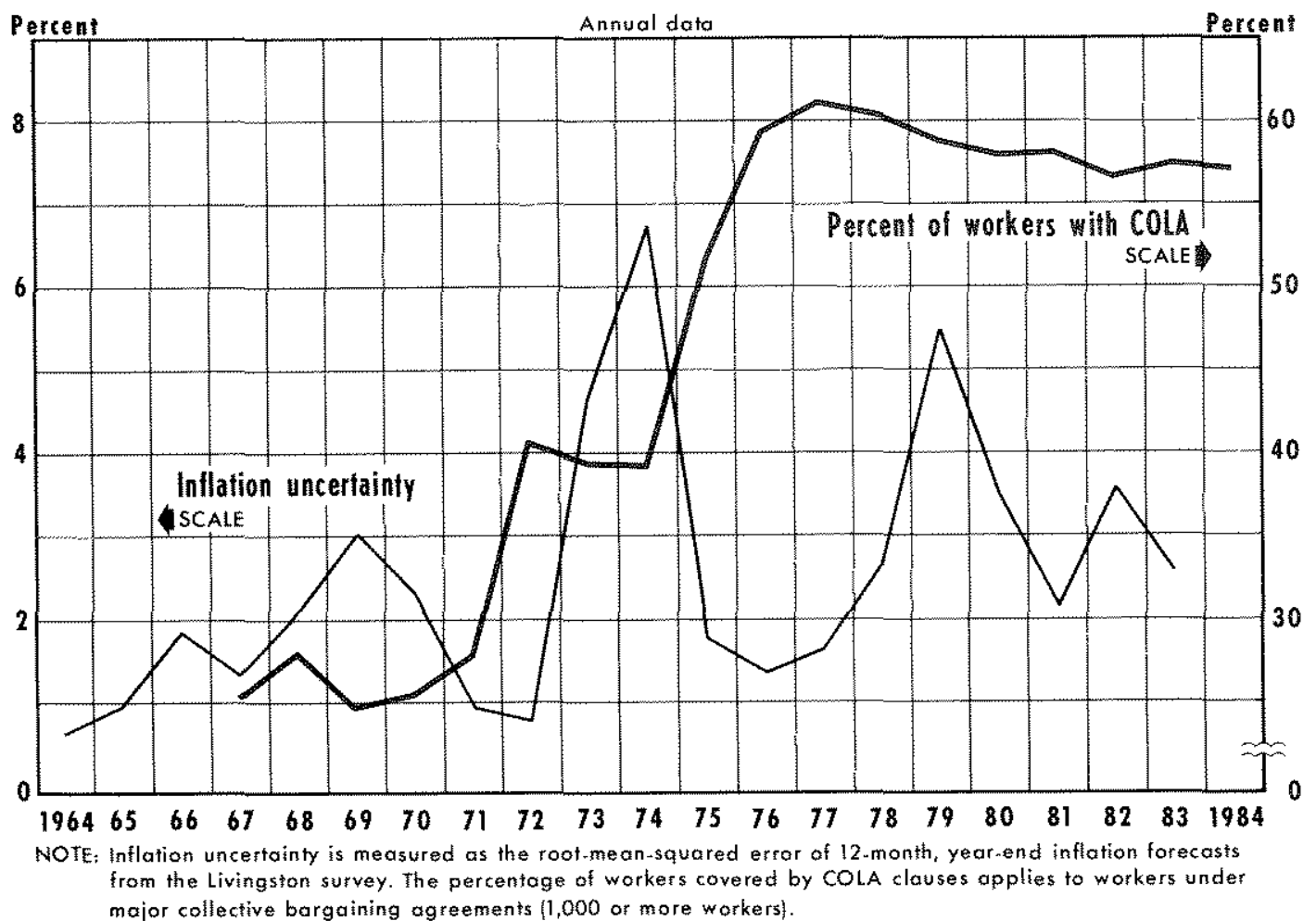

percent level; for three years earlier $(0.51)$, it is significant at the 5 percent level. ${ }^{16}$

There is evidence also that indexation offers an alternative to shortening the duration of contracts in the face of greater inflation uncertainty. Christofides and Wilton find that the response of contract duration to inflation uncertainty is less in indexed than in nonindexed contracts.

\section{Labor Market Adjustments and the Peal Effects of Inflation Uncertainty}

Labor market adjustments that lead to more flexible nominal wages also should lead to a reduction in the impact of inflation uncertainty on emplovment and output growth. In the extreme, if all wages could be costlessly indexed to eliminate the risk arising from

\footnotetext{
"Hendricks and Kahn (1983) also find a positive impact of inflation uncertainty on the probability that a given wage contract is indexed.
}

unanticipated inflation, inflation uncertainty would have no impact on the supply of labor: ${ }^{17}$ However, the problems of imperfect price level measures and delays in the availability of price level data make perfect indexation impossible. ${ }^{18}$ There are also costs of providing greater indexation, one of which is deseribed in the next section.

Figure 3 shows what happens in the labor market as these adjustments occur. The initial effect of greater inflation uncertainty was illustrated by the movement of the labor supply curve from $S_{1}$ to $S_{2}$. As measures to reduce the risk associated with inflation uncertainty are taken, the supply curve shifts back to the right - to $S_{3}$, for instance. This "second-round" effect of inflation uncertainty moves emplovment and the expected real wage back toward their original levels - to $\mathrm{O}_{3}^{*}$ and

\footnotetext{
${ }^{17}$ See Amihud.

${ }^{1}$ See Alchian and Klein (1973) for a discussion of the technical problems associated with price indexes.
} 
$w_{3}^{*}$. Because indexation is imperfect, the supply curve does not shift all the way back to its original position al $S_{1}$, so there remains a net reduction of employment. Because less market output is produced with lower employment even though the same level of productive resources is available to the economy, this represents a net loss from inflation uncertainty. ${ }^{19}$

\section{EFFECTS OF INCREASED RESPONSIVENESS OF WAGES TO INFLATIONARY SHOCKS}

The preceding section showed that labor markets adapt to greater inflation uncertainty in ways that increase the responsiveness of nominal wages to an inflationary shock. This type of labor market adjustment has consequences on the economy beyond those illustrated above, and the implications differ depend ing on the source of the inflationary shock.

\section{Nominal Shocks}

In the face of a purely nominal shock, such as an unanticipated change in nominal aggregate demand produced by an unexpected change in the money supply, the greater responsiveness of nominal wages increases the stability of output growth and unemployment: consequently, for nominal shocks, indexing improves the efficiency of the labor market. If nominal wages adjust slowly and if the growth rate of the money supply is reduced the result is an eventual increase in real wages when the inflation rate fals. This occurs even if workers and firms anticipate the change in monetary policy as long as some of them are still covered by labor contracts negotiated before this expecta-

\footnotetext{
${ }^{19}$ It should be emphasized that this is a partial equitibrium analysis; interaction between the labor market and other markets is not considered. In particutar, the results concerning the impact of inflation uncertainty on employment and wages could be attered if, for example, greater inflation uncertainty caused a reduction in investment and a lower capital-labor ratio for the economy.

Furthermore, the analysis has not dealt with all of the implications of costly indexing. Under the assumptions of the analysis, it is the risk-averse workers who desire indexing, and the risk-neutral fitms must be paid to provide it, since it is costly. At the margin, the value of a higher degree of indexing to the workers (the amount they are willing to pay) equals the cost of indexing to the firm. If, however, the marginal cost of indexing is constant white its marginal value is declining, then the irm profits from providing a higher degree of indexing. In other words, in the presence of higher risk, the riskneutral firm profits from the risk aversion of its workers. This implies a higher demand for labor as the degree of indexation increases, though this effect should hot be large enough to atter the conclusion that greater inflation uncertainty leads to reduced employment.
}

tion was formed. ${ }^{20}$ Assuming that contracts are not renegotiated prior to their expiation, the quantity of labor demanded by business firms will be reduced and the quantity supplied by workers will be increased

This was illustated in figure 2 as an increase in the real wage from $w_{1}^{*}$ to $w_{3}$ and an excess supply of labor $\left(\mathrm{O}_{3}-\mathrm{Q}_{2}\right)$. The excess supply of labor results in an increase in the rate of unemployment, and the decline in the quantity of labor demanded causes a reduction in the growth rate of real output. If, however, nominal wage growth adjusts downward more quickly in response to the contractionary monetary policy lbecause of indexation, for example, the impact on both the quantity of labor demanded and supplied is recluced.

\section{Real Shocks}

If the inflationary shock is due to a real disturbance, indexation makes it more difficult for the economy to adjust to the shock. This is because automatic cost of-living adjustments prevent (at least temporariv) the changes in real wages that are required in the face of real shocks to the economy. This is an important cost of indexing. For example, a substantial increase in the relative price of energy leads to higher prices in general because of energy's role as a factor of production for many goods. Because the costs of production increase. producers are willing to supply less at any given price than they were before the shock. As a consequence, the demand for labor falls as well, thereby lowering the equilibrium real wage.-1

In figure 4 , the reduction in the demand for labor from $\mathrm{D}_{1}$ to $\mathrm{D}_{2}$ results in a reduction in the equilibrium real wage from $w_{1}^{*}$ to $w_{2}^{*}$. As the price level increases due to the energy shock, the indexation of wages exacerbates the effect of the shock by preventing the needed decline in the real wage and causing excess supply of labor of the amount $\left(\mathrm{Q}_{1}^{*}-\mathrm{O}_{23}\right)$. In the absence of indexation, however, nominal wages need not rise in proportion to the rise in prices, and the real wage can decline to its equilibrium level, $w_{2}^{*}$, with the employment level at $\mathrm{Q}_{2}^{*}$. Thus, the impact of the energy shock on the economy is reduced.

In the event of a positive real shock - one that results in an increase in output and the demand for

\footnotetext{
20 See Fischer (1977b).

the discussion assumes that labor and energy are comptementary inputs, at least in the short-run - the period for which this analysis applies.

${ }^{22}$ See Gordon (1984) for a simple model of the effects of an aggregate supply shock on the economy.
} 


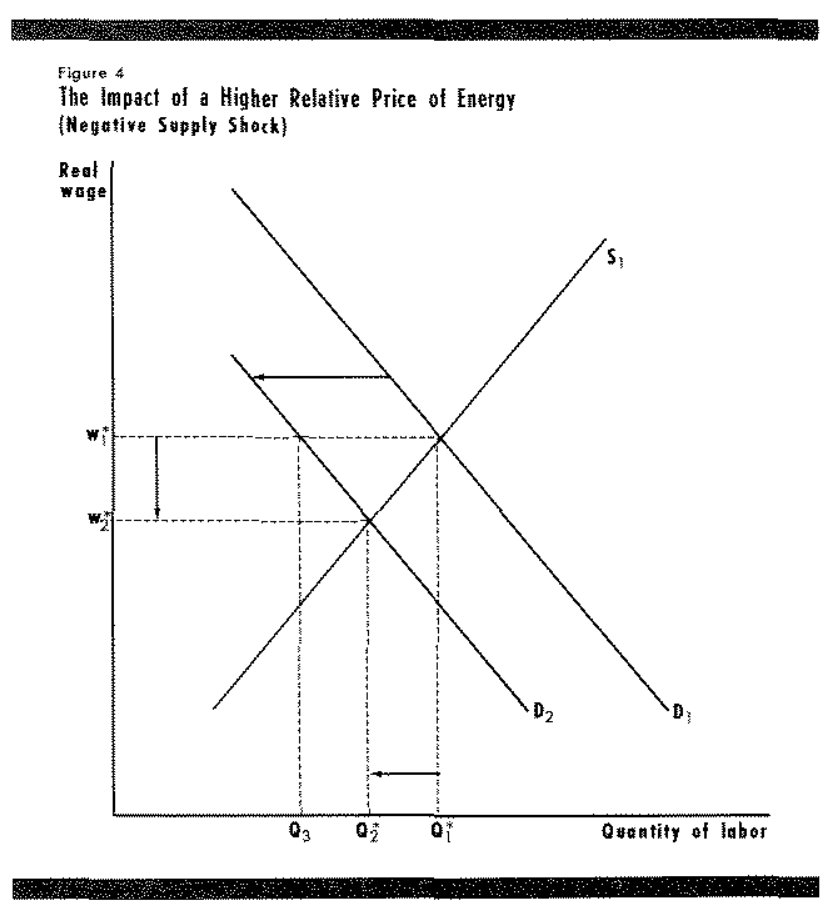

labor; such as increased productivity of labor - the equilibrium real wage and emplovment level will rise. If however, indexation results in the maintenance of a constant real wage, there will be no increase in employment as long as the supply of labor curve slopes upward; instead, an excess demand for labor will result $^{23}$

Thus, in an economy subject to both real and nominal economic shocks, the optimal degree of indexing is less than 100 percent. ${ }^{34}$ This has indeed been the case in the United States; the annual change in wages due to escalator clauses was only 57 percent of the annual change in the Consumer Price Index on average from $1968-777^{25}$

\section{CONCLUSION}

Inflation uncertainty has risen with inflation rates over the last 20 years. This uncertainty affects the labor

\footnotetext{
${ }^{23}$ The conclusion of Fischer (1977a) and Gray that indexation always destabilizes output in the face of a real disturbance arises from their assumption that employment is demand-determined. Cukierman (1980) shows that, for a positive supply shock, indexation actually makes employment and output more stable (but lower) under the assumptions about the determination of employment used in this article.

${ }^{24}$ This result from Gray's model is not affected by her assumption about the determination of employment. Maital (1984) discusses some of the consequences of nearly 100 percent indexing of payments in Israel.

${ }^{25}$ See Sheifer, p. 15
}

maket and reduces the welfare of society. The major effect on the labor market of greater inflation uncer" tainty is reduced efficiency in allocating labor resources. The end result is reduced employment and output growth, higher unemployment and more complex wage contract negotiations.

The labor market has adapted to greater inflation uncertainty by reducing the duration of labor contracts and increasing the prevalence of indexation. As a result, nominal wages have exhibited a greater responsiveness to inflationary shocks. The consequences of these events on the economy include reductions in both the short-run impact of monetary policy on output and the ability of the economy to adjust to a real supply shock (such as an energy crisis). Iabor market adaptations reduce but do not completely offset the impact of a given level of inflation uncertainty on the economy

\section{REFERENCES}

Alchian, Armen A., and Benjamin Klein. "On a Correct Measure of Inflation," Journal of Money, Credit and Banking (February 1973), pp. 173-91.

Amihud, Yakov. "Price-Level Uncertainty, Indexation and Employment," Southern Economic Journal (January 1981), pp. 776-87.

Ashenfelter, Orley, and George E. Johnson. "Bargaining Theory, Trade Unions, and Industrial Strike Activity," American Economic Feview (March 1969), pp. 35-49.

Azariadis, Costas. "Implicit Contracts and Underemployment Equilibria," Joumal of Political Economy (December 1975), pp. $1183-202$.

Baily, Martin Neil. "Wages and Employment under Uncertain De. mand," Review of Economic Studies (January 1974), pp. 37-50.

Barro, Robert J. 'Long-Term Contracting, Sticky Prices, and Monetary Policy," Journal of Monetary Economics (July 1977), pp. 30516.

Carlson, John A. "A Study of Price Forecasts," Annals of Economic and Social Measurement (Winter 1977), pp. 27-56.

Carlton, Dennis w. "The Disruptive Effect of Inflation on the Organization of Markezs." in Robent E. Hall, ed., Intlation: Causes and Effects (The University of Chicago Press, 1982), pp. $139-52$.

Christofides, L. N., and D. A. Wilton. "The Determinants of Contract Length: An Empirical Analysis Based on Canadian Micro Data," Joumal of Monetany Economics (August 1983), pp. 309-19.

Cukierman, Alex. "The Effects of Wage Incexation on Macroeconomic Fluctuations: A Generalization," Journal of Monetary Economics (April 1980), pp. 147-70.

Cukierman. Alex, and Paul Wachtel. "Inflationary Expectations: Reply and Further Thoughts on inflation Uncertainty," American Economic Review (June 1982), pp. 508-12.

Fischer, Stanley. "Wage Indexation and Macroeconomic Stability," in Karl Brunner and Allan H. Meltzer, eds., Stabilization of the Domestic and International Economy, Camegie-Rochester Conference Series on Public Policy, vol. 5 (1977a), pp. $107-47$

"Long-Term Contracts, Rational Expectations, and the Optimal Money Supply Rule," Journal of Political Economy (February 1977b), pp. 191-205. 
- "Adapting to Infiation in the United States Economy," in Inflation: Causes and Effects, pp. 169-88. See Carlton.

Friedman, Milton, "Nobel iecture: Inflation and Unemployment," Joumal of Political Economy (June 1977), pp. 451-72.

Gordon, Donald F. "A Neo-Classical Theory of Keynesian Unem" ployment," Economic Inquiry (December 1974), pp. 431-59.

Gordon, Robert J. "Supply Shocks and Monetary Policy Revisited," American Economic Review (May 1984), pp. 38-43.

Gray, Jo Anna. "Wage Indexation: A Macroeconomic Approach," Journal of Monetary Economics (April 1976), pp. 221-35.

Hamemesh. Danie S. "Inflation and Labo*Market Adjustment," Working Paper No. 1153 (National Bureau of Economic Research. Jure 1983)

Hamermesh, Daniel S., and Albert Rees. The Economics of Work and Pay, Third Edition (Harper \& Row, Publishers. 1984).

Hendricks, Wallace E., and Lawrence M. Kahn. "Cost-of-Living Clauses in Union Contracts: Determinants and Effects," Industrial and Labor Relations Review (April 1983), pp. 447 60 .

Holland, A, Steven. "Does Higher Inflation Lead to More Uncertain Inflation?" this Review (February 1984), pp. 15-26.

Kantor, Latirence $G$. "inflation Uncertainty and Intlation Hedging," Federal Reserve Bank of Kansas City Economic Review (Septembef-October 1983), pp. 24-37
Katz. Eliakim, and Jacob Rosenberg. "Inflation Variability, Reatwage Variabitity and Production Inefficiency," Economica (November 1983), pp. 469-75.

L_evi, Maurice D., and John H. Makin. "Inflation Uncertainty and the Phillps Curve: Some Empirical Evidence." American Economic Review (December 1980), pp. 1022-27.

Lucas, Robert E., Jr. "Some International Evidence on OutputInflation Tradeoffs," American Economic Review (June 1973), pp. $326-34$

Maital, Shlomo. "The Six-Year War," across the board (May 1984), pp. $12-18$.

Mulfneaux, Donald J. "Unemployment, Industrial Production, and Inflation Uncertainty in the Unized States," Review of Economics and Statistics (May 1980), pp. 163-69.

Ratti, Ronald A. "The Effects of Inflation Surprises and Uncertainty on Real Wages" (unpublished paper, University of MissouriColumbia, 1983).

Sheifer, Victor J. "Cost-of-Living Adjustment: Keeping Up With Inflation?" Monthy Labor Review ("June 1979), pp. 14-17.

U.S. Department of Labor. Monthy Labor Review, various issues. 